\title{
Chemical Kinetic Modeling of a Methane Opposed Flow Diffusion Flame and Comparison to Experiments
}

\author{
N.M. Marinov, W.J. Pitz and C.K. Westbrook \\ Lawrence Livermore National Laboratory \\ A.M. Vincitore and S.M. Senkan \\ University of California, Los Angeles \\ A.E. Lutz \\ Sandia National Laboratory, Livermore \\ This paper was prepared for submittal to the \\ Western States Section/Combustion Institute Spring Meeting \\ University of California, Berkeley \\ Berkeley, $C A$ \\ March 23-24, 1998
}

January 1998

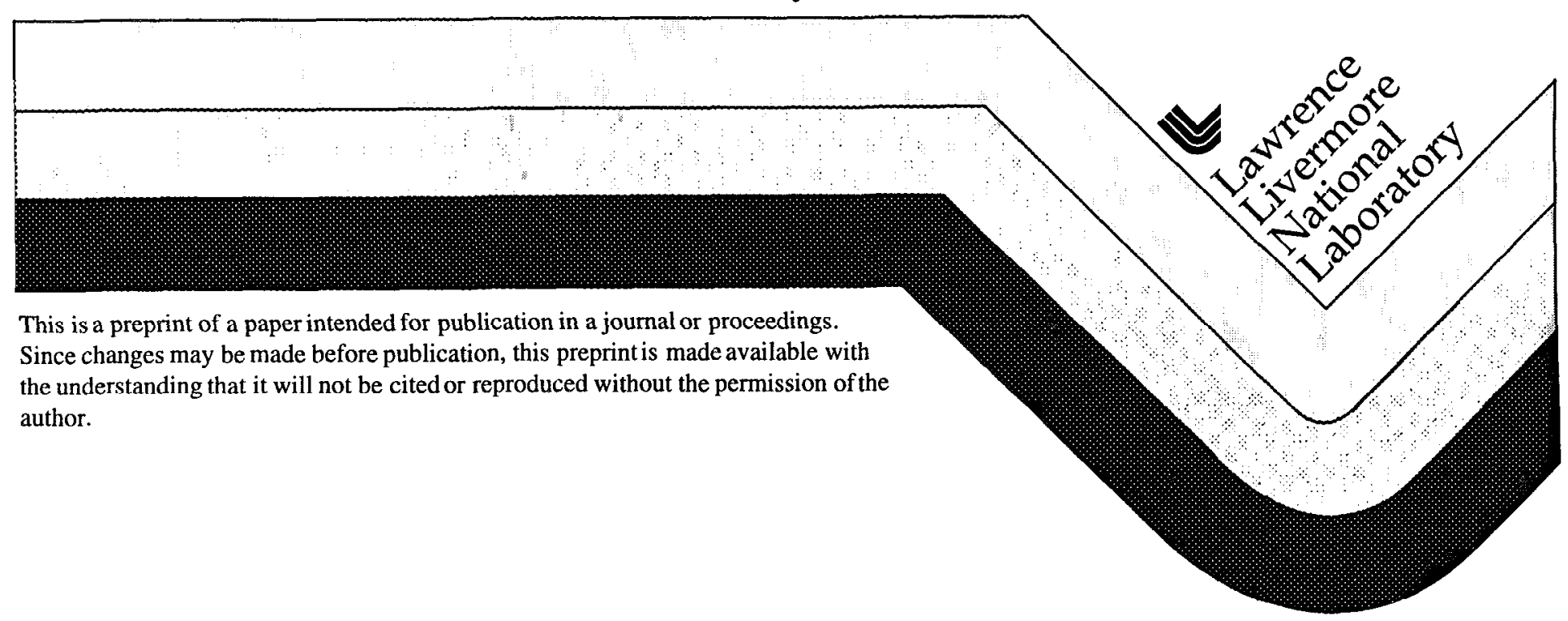




\section{DISCLAIMER}

This document was prepared as an account of work sponsored by an agency of the United States Government. Neither the United States Government nor the University of California nor any of their employees, makes any warranty, express or implied, or assumes any legal liability or responsibility for the accuracy, completeness, or usefulness of any information, apparatus, product, or process disclosed, or represents that its use would not infringe privately owned rights. Reference herein to any specific commercial product, process, or service by trade name, trademark, manufacturer, or otherwise, does not necessarily constitute or imply its endorsement, recommendation, or favoring by the United States Government or the University of California. The views and opinions of authors expressed herein do not necessarily state or reflect those of the United States Government or the University of Califomia, and shall not be used for advertising or product endorsement purposes. 


\title{
Chemical Kinetic Modeling of a Methane Opposed Flow Diffusion Flame and Comparison to Experiments
}

\author{
N. M. Marinov, W. J. Pitz, C. K. Westbrook \\ Lawrence Livermore National Laboratory \\ Livermore, CA 94551
}

A. M. Vincitore, S. M. Senkan

Department of Chemical Engineering, University of California

Los Angeles, CA 90095

A. E. Lutz

Sandia National Laboratories

Livermore, CA 94551

Topic: Soot, PAH and Air Toxics

Type: Oral Presentation preferred

Current word count:

text: 3657 words

Figs.: $10 * 200=2000$ words.

Total: 5657 words

Corresponding author:

William J. Pitz

Lawrence Livermore National Laboratory

P.O. Box 808

Livermore, CA 94551

USA

Phonc: (510) 422-7730

Fax: (510) 422-2644

email: pitz@llnl.gov 


\title{
Chemical Kinetic Modeling of a Methane Opposed Flow Diffusion Flame and Comparison to Experiments
}

\author{
N. M. Marinov, W. J. Pitz, C. K. Westbrook \\ Lawrence Livermore National Laboratory \\ Livermore, CA 94551 \\ A. M. Vincitore, S. M. Senkan \\ Department of Chemical Engineering, University of California \\ Los Angeles, CA 90095
}

A. E. Lutz

Sandia National Laboratories

Livermore, CA 94551

\section{ABSTRACT}

The chemical structure of an opposed flow, methane diffusion flame is studied using a chemical kinetic model and the results are compared to experimental measurements. The chemical kinetic paths leading to aromatics and polycyclic aromatics hydrocarbons (PAHs) in the diffusion flame are identified. These paths all involve resonantly stabilized radicals which include propargyl, allyl, cyclopentadienyl, and benzyl radicals.

The modeling results show reasonable agreement with the experimental measurements for the large hydrocarbon aliphatic compounds, aromatics, and PAH's. The benzene was predicted to be formed primarily by the reaction sequence of Allyl+Propargyl $\leftrightarrow$ Fulvene $+\mathrm{H}+\mathrm{H}$ followed by fulvene isomerization to benzene. Naphthalene was modeled using the reaction of benzyl with propargyl, while the combination of cyclopentadienyl radicals were shown to be a minor contributor in the diffusion flame. The agreement between the model and experiment for the four-ring PAH's was poor. 


\section{INTRODUCTION}

This study is directed towards two important problems in combustion research. The first is emission of aromatics and polycyclic aromatic hydrocarbons (PAH's) from diffusion flames. The emission of this important class of species from stationary combustion sources is regulated by the U.S. 1990 Clean Air Act Amendments. The second problem is the mechanism of formation of soot precursors in diffusion flames. Soot emissions from heavy-duty diesel engines are regulated in the U.S. by EPA to below $0.1 \mathrm{gm} / \mathrm{bhp}-\mathrm{hr}$ which is a factor of 10 below the unregulated levels existing prior to 1998. Because of the trade-off between regulated soot emissions and NOx emissions, it is difficult to reduce the soot emissions to the required levels. Therefore, the development of a better understanding of the mechanism of soot formation should help indicate how to reduce these emissions. The chemical evolution of many species that are likely to be important soot precursors are computed in the present study and compared to experimental measurements. The proposed soot precursors include acetylene, resonantly stabilized radicals, and PAH's.

Previous computational modeling work on methane diffusion flames has been very limited. The modeling studies have primarily focused on soot formation occurring in co-flowing Wolfhard-Parker or axisymmetric diffusion flame burners $[1,2]$, or a counter-flow diffusion flame [3]. The amount of modeling work performed on elucidating the chemical kinetics issues involved in these burner systems $[4,5]$ has been very limited. In particular, we are aware of no detailed chemical kinetic modeling work on the high molecular weight, aromatic and PAH growth chemistry that can occur in methane diffusion flames. This is primarily due to an overall scarcity of detailed and spatially-resolved flame structure measurements which only recently have become available for modeling [6,7].

In the present study, an opposed flow diffusion flame was chosen for the study of molecular weight growth processes that can be important to $\mathrm{PAH}$ and soot formation. The concentration profiles of reactants and major and minor products including aromatics and $\mathrm{PAH}^{\prime}$ s are computed and compared to experimental 
measurement. The major chemical reaction pathways that lead to production of these reaction intermediates and by-products are also determined using reaction rate analysis.

\section{EXPERIMENTAL APPARATUS}

A schematic of the opposed flow diffusion flame burner is given in Fig. 1. The details of the experimental apparatus has been described elsewhere [7] and will be summarized here. A flat, opposed-flow, methane diffusion flame was stabilized between two 1.0 inch ID burner ports. The oxidizer stream composed of $20 \% \mathrm{O}_{2}$ (99\% purity) and $80 \% \operatorname{Ar}(99.99 \%$ purity) was introduced through the top burner port which also possessed an annular Ar shield gas to protect the flame from the surrounding air. The fuel stream, containing $75 \% \mathrm{CH}_{4}(99.99 \%$ purity) and $25 \% \mathrm{Ar}$ was introduced through the bottom port which is surrounded by an annular exhaust flow. Gas flows were regulated using high accuracy mass flow controllers. The outlet flow velocities (calculated at $298 \mathrm{~K}$ and $1 \mathrm{~atm}$.) for the oxidizer port and fuel port were $16.12 \mathrm{~cm} / \mathrm{s}$ and $13.16 \mathrm{~cm} / \mathrm{s}$ respectively. Samples were withdrawn with a heated quartz micro-probe with a $100 \mu \mathrm{m}$ orifice and transported through a silica-lined heated tube to a Gas Chromatograph/Mass Spectrometer system. A quartz wool filter was placed inside the probe to trap soot particles. The entire sampling system was maintained at $300^{\circ} \mathrm{C}$ to minimize adsorption of large molecular weight PAH. Major species were analyzed by thermal conductivity detector and minor species by mass spectrometer. Species were identified both by matching retention times and mass spectral finger prints. Species concentrations were determined by either direct calibration or by the use of mass spectral ionization cross section method. The accuracy of the latter is estimated as a factor of 2 [7]. The accuracy of the mole fractions of major species by direct calibration is estimated to be $\pm 15 \%$. Concentration measurements were made by moving the entire burner assembly up or down with respect to the fixed sampling probe. Positional accuracy with the concentration and temperature measurements of respect to the burner port is estimated to be $\pm 0.25 \mathrm{~mm}$. Temperature measurements were obtained with silica-coated, $\mathrm{Pt}-13 \% \mathrm{Rh} / \mathrm{Pt}$ thermocouple having a $0.15 \mathrm{~mm}$ diameter bead. The 
temperature profile was corrected for radiation losses. The uncertainty in the absolute temperature is estimated to be within $100 \mathrm{~K}$.

\section{CHEMICAL KINETICS MECHANISM AND NUMERICAL MODEL}

\section{Chemical Kinetic Mechanism}

The detailed chemical kinetic model used in the numerical calculations was based on a hierarchical structure of hydrocarbon kinetics starting from hydrogen and building up to n-butane. The chemical kinetic model was extended to include cyclopentadiene, benzene, substituted aromatics, and polycyclic hydrocarbons from one to four fused aromatic rings. Earlier versions of the detailed chemical kinetic model have been documented elsewhere [8-10]. The thermochemical properties of the chemical compounds were primarily taken from the CHEMKIN Thermodynamic Database [11], the thermodynamics literature [12] or calculated by group additivity techniques as described by Benson [13], and fitted to a polynomial form using THERM [14]. Transport properties were obtained from the Sandia CHEMKIN Transport database [15] or by using methods describe by Wang and Frenklach [16]. The complete listing of the chemical kinetic mechanism, thermochemistry, and transport can be obtained by contacting marinov1@llnl.gov. The present model consists of 680 reactions and 156 species.

The mechanism was slightly altered from our previous publication [9], and those changes were made to improve several features of the chemical model. In particular, the fall-off chemical kinetics for $\mathrm{C}_{2} \mathrm{H}_{3}+\mathrm{H}(+\mathrm{M}) \leftrightarrow \mathrm{C}_{2} \mathrm{H}_{4}(+\mathrm{M})$, $\mathrm{CH}_{2}+\mathrm{CO}(+\mathrm{M}) \leftrightarrow \mathrm{CH}_{2} \mathrm{CO}(+\mathrm{M}), \mathrm{CH}_{2} \mathrm{O}+\mathrm{H}(+\mathrm{M}) \leftrightarrow \mathrm{CH}_{3} \mathrm{O}(+\mathrm{M})$, and $\mathrm{CH}_{2} \mathrm{O}+\mathrm{H}$ $(+\mathrm{M}) \leftrightarrow \mathrm{CH}_{2} \mathrm{OH}(+\mathrm{M})$ were taken from [17], the reaction expressions and rate constants to $\mathrm{pC}_{3} \mathrm{H}_{5}+\mathrm{H} \leftrightarrow \mathrm{C}_{3} \mathrm{H}_{6}\left(1.0 \mathrm{E}+14 \mathrm{~cm}^{3} / \mathrm{mol} / \mathrm{sec}\right), \mathrm{sC}_{3} \mathrm{H}_{5}+\mathrm{H} \leftrightarrow \mathrm{C}_{3} \mathrm{H}_{6}$ $\left(5.0 \mathrm{E}+13 \mathrm{~cm}^{3} / \mathrm{mol} / \mathrm{sec}\right), \mathrm{pC}_{3} \mathrm{H}_{5}+\mathrm{HO}_{2}=\mathrm{C}_{3} \mathrm{H}_{6}+\mathrm{O}_{2}\left(2.0 \mathrm{E}+12 \mathrm{~cm}^{3} / \mathrm{mol} / \mathrm{sec}\right)$, $\mathrm{sC}_{3} \mathrm{H}_{5}+\mathrm{HO}_{2} \leftrightarrow \mathrm{C}_{3} \mathrm{H}_{6}+\mathrm{O}_{2}\left(1.0 \mathrm{E}+12 \mathrm{~cm}^{3} / \mathrm{mol} / \mathrm{sec}\right)$, and $\mathrm{aC}_{3} \mathrm{H}_{5}+\mathrm{HO}_{2} \leftrightarrow \mathrm{C}_{3} \mathrm{H}_{6}+\mathrm{O}_{2}$ $(3.0 \mathrm{E}+12 \mathrm{~cm} 3 / \mathrm{mol} / \mathrm{sec})$ were changed to reflect their estimated rate in the exothermic direction, and the $\mathrm{C}_{10} \mathrm{H}_{7} \mathrm{OH}$ heat of formation at $298 \mathrm{~K}$ was recalculated to be $-4.65 \mathrm{kcal} / \mathrm{mol}$. The mechanism was further adjusted by lowering the rate constants 
of $\left(\mathrm{CH}_{3} \mathrm{CCCH}_{2}\right.$ or $\left.\mathrm{CH}_{3} \mathrm{CHCCH}\right)+\mathrm{H}_{2} \mathrm{CCCH} \leftrightarrow \mathrm{C}_{6} \mathrm{H}_{5} \mathrm{CH}_{2}$ (benzyl) $+\mathrm{H}$ from

$3.0 \mathrm{E}+12 \mathrm{~cm}^{3} / \mathrm{mol} / \mathrm{sec}[8]$ to the present value of $1.0 \mathrm{E}+11 \mathrm{~cm}^{3} / \mathrm{mol} / \mathrm{sec}$ and

$2\left(\mathrm{CH}_{3} \mathrm{CCCH}\right.$ or $\left.\mathrm{CH}_{3} \mathrm{CHCCH}\right) \leftrightarrow \mathrm{CH}_{3} \mathrm{C}_{6} \mathrm{H}_{4} \mathrm{CH}_{2}(\mathrm{O}-\mathrm{xylyl})+\mathrm{H}$ from $3.0 \mathrm{E}+12 \mathrm{~cm}^{3} / \mathrm{mol} / \mathrm{sec}$

[8] to the present value of $1.0 \mathrm{E}+9 \mathrm{~cm}^{3} / \mathrm{mol} / \mathrm{sec}$. These changes were made in order to

obtain better agreement with the experimental measurements for toluene and o-xylene. The previous rate expressions reflected an overprediction of toluene by nearly a factor of 50, and o-xylene was computed in excess of $100 \mathrm{ppm}$ compared to the experimental upper limit of $0.1 \mathrm{ppm}$. The rather large reduction of these rate constants reflects that these pathways are most likely to be intercepted prior to forming the branched aromatic radical and $\mathrm{H}$-atom. Further analysis of the propargyl combination with itself and other methylated propargyl radicals is needed to obtain a better understanding of the complex chemistry occurring for these reactions.

\section{Numerical Model}

The numerical model used was the one-dimensional, opposed flow diffusion flame (OPPDIF) code written by Lutz et al. [18]. It computes the steady-state solution for an axisymmetric diffusion flame stabilized between two opposing nozzles. The input to the OPPDIF code requires fuel and oxidizer mass flow rates. The fuel mass flow rate was reduced in the calculation from $1.06 \times 10^{-2}$ to $6.0 \times 10^{-3} \mathrm{gm} \cdot \mathrm{cm}^{-2} \mathrm{~s}^{-1}$ to include the effect of the shield gas flow on the position of the flame. The shield gas flow originates from the oxidizer port side and is exhausted on the fuel port side (Fig. 1). The shield gas flow opposed the fuel flow and shifts the position of the flame toward the fuel port. The fuel flow rate was reduced to include the effect of the shield and exhaust gas flows on the position of the flame. Reduction of the fuel flow rate moved the stagnation plane and flame in the calculation to the same position as seen in the experiment. The position of the stagnation plane in the calculation was $3.6 \mathrm{~mm}$ which was within the limits of experimental value $(4.0 \pm 0.5$ $\mathrm{mm}$ ). A specified temperature profile (Fig. 2) based on the raw experimental measurements and corrected for radiation losses was used in the calculations. The peak of the temperature profile occurred at $7.0 \mathrm{~mm}$ with a maximum temperature of $1858 \mathrm{~K}$. 


\section{RESULTS AND DISCUSSION}

In this section, the results of the numerical model are compared to the experimental results. The primary paths leading to aromatics and PAH's and their precursors are identified. These paths will be seen to involve the reaction of resonantly-stabilized radicals. These radicals are relatively stable and their concentrations are relatively high for a radical species so that their associated radicalradical reactions can be important for aromatic ring growth. The key differences between aromatic and PAH formation in a diffusion flame compared to previously examined premixed flames are highlighted. The computed and measured profiles of the reactants are compared in Fig. 2. Calculations show methane and $\mathrm{O}_{2}$ are mainly consumed by $\mathrm{H}$ atoms through $\mathrm{CH}_{4}+\mathrm{H} \leftrightarrow \mathrm{CH}_{3}+\mathrm{H}_{2}$ and $\mathrm{O}_{2}+\mathrm{H} \leftrightarrow \mathrm{OH}+\mathrm{O}$. The major species computed and measured are given in Fig. 3. The computed and measured $\mathrm{CH}_{4}, \mathrm{O}_{2}, \mathrm{Ar}, \mathrm{CO}, \mathrm{CO}_{2}, \mathrm{H}_{2}$ and $\mathrm{H}_{2} \mathrm{O}$ species in Figs. 2-3 are in reasonable agreement. The $\mathrm{C}_{2}$ and $\mathrm{C}_{3}$ aliphatic species are shown in Fig. 4. The most important aromatic and PAH precursor is acetylene. Acetylene addition to an aromatic radical can lead to $\mathrm{PAH}$ growth [19]. The computed peak height is $30 \%$ lower than the measured peak which is reasonable agreement considering uncertainties in the temperature profile, the species concentrations $( \pm 15 \%)$ and the rate constants for $\mathrm{C}_{2} \mathrm{H}_{2}$ formation. The major routes forming acetylene are vinyl decomposition $\left(\mathrm{C}_{2} \mathrm{H}_{3}(+\mathrm{M}) \leftrightarrow \mathrm{C}_{2} \mathrm{H}_{2}+\mathrm{H}(+\mathrm{M})\right)$ and $\mathrm{H}_{2}$ elimination from ethylene $\left(\mathrm{C}_{2} \mathrm{H}_{4}+\mathrm{M} \leftrightarrow \mathrm{C}_{2} \mathrm{H}_{2}+\mathrm{H}_{2}+\mathrm{M}\right)$. This compares to the rich, premixed, propane and $n-$ butane flames [3,4] where the main formation path was $\mathrm{C}_{2} \mathrm{H}_{3}+\mathrm{O}_{2} \leftrightarrow \mathrm{C}_{2} \mathrm{H}_{2}+\mathrm{HO}_{2}$ with a secondary contribution from $\mathrm{C}_{2} \mathrm{H}_{3}(+\mathrm{M}) \leftrightarrow \mathrm{C}_{2} \mathrm{H}_{2}+\mathrm{H}(+\mathrm{M})$. The reasons for this difference are due to a limited amount of $\mathrm{O}_{2}$ available for attack on the vinyl radical in the region where vinyl is consumed in the diffusion flame and the temperature in the diffusion flame (about $1850 \mathrm{~K}$ ) being much higher than in the premixed flame (about $1600 \mathrm{~K}$ ).

The modelled $\mathrm{C}_{4}$ aliphatics are in reasonable accord with the experimental data as shown in Fig. 5. The $\mathrm{C}_{4} \mathrm{H}_{6}$ measurement is an aggregate measurement of four differing isomers $\left(\mathrm{CH}_{2} \mathrm{CHCHCH}_{2}, \mathrm{CH}_{3} \mathrm{CHCCH}_{2}, \mathrm{CH}_{3} \mathrm{CCCH}_{3}, \mathrm{CH}_{3} \mathrm{CH}_{2} \mathrm{CCH}\right)$. The model indicates that $\mathrm{CH}_{3} \mathrm{CHCCH}_{2}$ and $\mathrm{CH}_{2} \mathrm{CHCHCH}_{2}$ are the two dominant 
$\mathrm{C}_{4} \mathrm{H}_{6}$ isomers formed and their combined concentration predicts fairly well the measured $\mathrm{C}_{4} \mathrm{H}_{6}$. The $\mathrm{CH}_{3} \mathrm{CHCCH}_{2}$ is formed from

$\mathrm{H}_{2} \mathrm{CCCH}$ (propargyl) $+\mathrm{CH}_{3} \leftrightarrow \mathrm{CH}_{3} \mathrm{CHCCH}_{2}$, while $\mathrm{CH}_{2} \mathrm{CHCHCH}_{2}$ is formed from the reaction sequence of $\mathrm{aC}_{3} \mathrm{H}_{5}+\mathrm{CH}_{3} \leftrightarrow 1-\mathrm{C}_{4} \mathrm{H}_{8}, 1-\mathrm{C}_{4} \mathrm{H}_{8}+\mathrm{H} \leftrightarrow \mathrm{C}_{4} \mathrm{H}_{7}+\mathrm{H}_{2}$, followed by $\mathrm{C}_{4} \mathrm{H}_{7} \leftrightarrow \mathrm{CH}_{2} \mathrm{CHCHCH}_{2}+\mathrm{H}$. The measured $\mathrm{C}_{4} \mathrm{H}_{4}$ concentration is fairly well modeled and primarily evolves from the dehydrogenation of $\mathrm{CH}_{3} \mathrm{CHCCH}_{2}$ and $\mathrm{CH}_{2} \mathrm{CHCHCH}_{2}$ by $\mathrm{H}$-atom and $\mathrm{OH}$ abstraction. The diacetylene $\left(\mathrm{C}_{4} \mathrm{H}_{2}\right)$ was a major problem in our previously modeling efforts of methane, ethane, ethylene, propane and n-butane premixed flames. We had consistently underpredicted that species by approximately one order of magnitude while in the current study its peak concentration is overpredicted by a factor of three. No major changes involving the $\mathrm{C}_{4}$ submechanism were made to obtain agreement with the diacetylene measurement. Diacetylene is primarily formed via $\mathrm{H}$-atom abstraction of the $\mathrm{C}_{4} \mathrm{H}_{4}$ by $\mathrm{OH}$ and $\mathrm{H}$-atom to form $\mathrm{H}_{2} \mathrm{CCCCH}$, whereupon the $\mathrm{H}_{2} \mathrm{CCCCH}$ decomposes to $\mathrm{C}_{4} \mathrm{H}_{2}+\mathrm{H}$. This pathway to diacetylene formation differs from our previous premixed flame modeling studies where $\mathrm{C}_{2} \mathrm{H}_{2}+\mathrm{C}_{2} \mathrm{H} \leftrightarrow \mathrm{C}_{2} \mathrm{H}_{2}+\mathrm{H}$ was determined to be the dominant route to diacetylene formation. The linear $\mathrm{C}_{5} \mathrm{H}_{6}$ and $\mathrm{C}_{6} \mathrm{H}_{6}$ compounds were not modeled in this study and are included in Fig. 4 as part of the complete data set for this flame.

The aromatic species are shown in Fig. 6. The peak in the benzene profile agrees well with the experimental value. All the experimental profiles are flatter than the curved computed profiles. This discrepancy could be due to transport property uncertainties, reactions between soot and aromatics that are not accounted for, or diffusion of species into the burner port which is not accounted for in the model. The main reactions producing benzene are isomerization from fulvene, propargyl self reaction, and the reaction of phenyl with $\mathrm{H}_{2}$ (Fig. 7). Fulvene is formed entirely by the reaction of resonantly-stabilized allyl and propargyl radicals: $\mathrm{aC}_{3} \mathrm{H}_{5}$ (allyl) $+\mathrm{H}_{2} \mathrm{CCCH} \leftrightarrow$ Fulvene $+\mathrm{H}+\mathrm{H}$. The mechanism of this reaction has been discussed previously [9]. After benzene, the next most-important aromatic observed experimentally is phenylacetylene whose peak value is well-predicted by the model (Fig. 6). Phenyl acetylene is principally formed by $\mathrm{C}_{6} \mathrm{H}_{5}+\mathrm{C}_{2} \mathrm{H}_{2} \leftrightarrow \mathrm{C}_{6} \mathrm{H}_{5} \mathrm{C}_{2} \mathrm{H}+\mathrm{H}$ in the 
region from the fuel-port to approximately $4.5 \mathrm{~mm}$ upstream and by styrene dehydrogenation to phenyl acetylene in the remainder of the diffusion flame. The $\mathrm{C}_{6} \mathrm{H}_{5}+\mathrm{C}_{2} \mathrm{H}_{2} \leftrightarrow \mathrm{C}_{6} \mathrm{H}_{5} \mathrm{C}_{2} \mathrm{H}+\mathrm{H}$ reaction reverses around $5 \mathrm{~mm}$ as the $\mathrm{H}$-atom concentration and temperature increases, and this step becomes the dominant phenyl acetylene removal reaction. The final aromatics experimentally observed are toluene and styrene whose peak values are overpredicted by the model by a factor of 20 and 7, respectively. Toluene is primarily formed by $\mathrm{C}_{6} \mathrm{H}_{6}+\mathrm{CH}_{3} \leftrightarrow \mathrm{C}_{6} \mathrm{H}_{5} \mathrm{CH}_{3}+\mathrm{H}$ and secondarily by the reaction sequence of $\mathrm{H}_{2} \mathrm{CCCH}+\mathrm{CH}_{3} \mathrm{CCCH}_{2} \leftrightarrow \mathrm{C}_{6} \mathrm{H}_{5} \mathrm{CH}_{2}+\mathrm{H}$ followed by $\mathrm{C}_{6} \mathrm{H}_{5} \mathrm{CH}_{2}+\mathrm{H} \leftrightarrow \mathrm{C}_{6} \mathrm{H}_{5} \mathrm{CH}_{3}$. The overprediction of toluene could be due to the inaccurate prediction of the $\mathrm{CH}_{3}$ radical concentration or the inadequate representation of the chemically activated $\mathrm{C}_{6} \mathrm{H}_{5}+\mathrm{CH}_{3} \leftrightarrow \mathrm{C}_{6} \mathrm{H}_{5} \mathrm{CH}_{3}+\mathrm{H}$ reaction. Styrene $\left(\mathrm{C}_{6} \mathrm{H}_{5} \mathrm{C}_{2} \mathrm{H}_{3}\right)$ is primarily formed by the reaction step, $\mathrm{C}_{6} \mathrm{H}_{5}+\mathrm{C}_{2} \mathrm{H}_{4} \leftrightarrow \mathrm{C}_{6} \mathrm{H}_{5} \mathrm{C}_{2} \mathrm{H}_{3}+\mathrm{H}$. It's overprediction is most likely due to the inadequate treatment of the styrene removal kinetics in the present model.

The two and three ring PAH's are shown in Fig. 8. The most abundant PAH experimentally measured is naphthalene, whose peak value was very well predicted. Again, the experimental PAH profiles have a flatter shape than the predicted profiles, for possible reasons given above. In the model, the reaction of resonantly stabilized benzyl and propargyl radicals lead to the production of about $95 \%$ of the naphthalene. The sequence of reactions is $\mathrm{C}_{6} \mathrm{H}_{5} \mathrm{CH}_{2}+\mathrm{H}_{2} \mathrm{CCCH} \leftrightarrow \mathrm{C}_{10} \mathrm{H}_{9}+\mathrm{H}$ and $\mathrm{C}_{10} \mathrm{H}_{9} \leftrightarrow \mathrm{C}_{10} \mathrm{H}_{8}+\mathrm{H}$. The remaining naphthalene was produced by the self reaction of resonantly-stabilized cyclopentadienyl radicals: $\quad c-\mathrm{C}_{5} \mathrm{H}_{5}+\mathrm{c}-\mathrm{C}_{5} \mathrm{H}_{5} \leftrightarrow$ Naphthalene $+\mathrm{H}+\mathrm{H}$. The mechanism of this reaction has been previously discussed by Melius et al. [20]. Acenaphthylene is predicted to be primarily formed by $\mathrm{C}_{10} \mathrm{H}_{7}+\mathrm{C}_{2} \mathrm{H}_{2} \leftrightarrow$ Acenaphthylene $+\mathrm{H}$ and secondarily by $\mathrm{C}_{10} \mathrm{H}_{7} \mathrm{C}_{2} \mathrm{H}+\mathrm{H} \leftrightarrow$ Acenaphthylene $+\mathrm{H}$. The model predicts acenaphthylene to have a broader concentration profile than the other two and three-ring PAH's contrary to experiment. The lack of an acenaphthylene oxidation submechanism is the principal contributor to this profile's broadening. Phenanthrene is exclusively formed by the reaction step, Indenyl $+\mathrm{c}-\mathrm{C}_{5} \mathrm{H}_{5} \leftrightarrow$ Phenanthrene $+\mathrm{H}+\mathrm{H}$. The phenanthrene is shown to be 
overpredicted by a factor of ten, and this is due to the overpredicted benzyl (toluene) concentrations. The benzyl plus acetylene reaction leads to indene formation (not shown), whereupon indene is converted to indenyl by $\mathrm{H}$-atoms. Anthracene is produced from phenanthrene isomerization, and its concentration is predicted to within a factor of four. The model indicates a peak concentration of anthracene will form although the experimental profile is fairly flat.

The four ring PAH's are shown in Fig. 9. The pyrene and fluoranthene were underpredicted by approximately two orders of magnitude. We have similarly underpredicted these compounds in our previous premixed flame studies. Further work is needed to understand the mechanisms that contribute to the formation of these species.

Figure 10 illustrates the important chemical pathways that lead to aromatic formation for the methane diffusion flame. Reaction of the fuel with $\mathrm{H}$ atoms leads to methyl radicals which then react with vinyl and ethylene to produce propene. Propene is subsequently dehydrogenated by $\mathrm{H}$-atoms eventually leading to the production of allyl, allene, propargyl, and $\mathrm{C}_{3} \mathrm{H}_{2}$. The resonantly stabilized allyl and propargyl radicals react to produce fulvene which rearranges to benzene. The alternative path to benzene formation involves the self-combination of propargyl radicals. This was shown previously to be the dominant benzene formation route in our previous studies of propane and n-butane premixed flames. In this study, approximately $25 \%$ of the benzene is produced by propargyl self-combination.

\section{Propargyl Reaction with Allyl and Benzyl Radicals}

Resonantly stabilized allyl and propargyl radicals are expected to be important precursors to aromatic formation in methane and natural gas diffusion flames. The combination of these radicals leads to the formation of 1,2,5-hexatriene or 1-hexen-5yne as energized adducts that may undergo collisional stabilization or isomerize to (non)conjugated cyclic products. The rate determining step in this cyclization process to dihydrofulvenes and subsequent fulvene formation is the addition of the allene moeity's central carbon to the end vinylic carbon forming a five-membered 
diradical ring [9]. This step requires overcoming a $29 \mathrm{kcal} / \mathrm{mol}$ barrier which is lower than the approximately $60 \mathrm{kcal} / \mathrm{mol}$ bond dissociation energy back to allyl and propargyl. The energized-complex/QRRK theory, as described by Dean [21], was used to analyze the kinetics for the allyl plus propargyl combination reaction. Using the BAC-MP4 potential energy surface generated by Melius [9], an input overall rate constant of $7.0 \mathrm{E}+13 \mathrm{~cm} 3 / \mathrm{mol} / \mathrm{sec}$, and a step size down value of $230 \mathrm{~cm}^{-1}$, rate constants were calculated at one atmosphere for $\mathrm{aC}_{3} \mathrm{H}_{5}+\mathrm{H}_{2} \mathrm{CCCH} \leftrightarrow$ Products. These rate constants for the reaction of $\mathrm{aC}_{3} \mathrm{H}_{5}+\mathrm{H}_{2} \mathrm{CCCH} \leftrightarrow \mathrm{Hydrofulvenyl}(\mathrm{C} 6 \mathrm{H} 7)+\mathrm{H}$, nonconjugated and conjugated dihydrofulvenes were determined to be 2.01E67T-16.0 $\operatorname{Exp}(-15280 \mathrm{~K} / \mathrm{T}), 7.934 \mathrm{E} 90 \mathrm{~T}^{-23.71} \operatorname{Exp}(-16825 \mathrm{~K} / \mathrm{T})$, and 2.317E89T-23.25 $\operatorname{Exp}(-16740 \mathrm{~K} / \mathrm{T}) \mathrm{cm}^{3} / \mathrm{mol} / \mathrm{sec}$ respectively. The sum of these rate constant values lies within a factor of two of our prescribed upper limit rate expression (5.56E20T-2.535Exp(-852K/T)) for $\mathrm{aC}_{3} \mathrm{H}_{5}+\mathrm{H}_{2} \mathrm{CCCH} \leftrightarrow \mathrm{Fulvene}+\mathrm{H}+\mathrm{H}$ in the $800 \mathrm{~K}-1800 \mathrm{~K}$ temperature range.

The benzyl radical is difficult to oxidize by $\mathrm{O}_{2}$ and is quite stable in high temperature flames. This allows benzyl to be formed in abundance relative to nonresonantly stabilized radicals, and makes it a good precursor candidate for forming multi-ring structures. The rate constant for $\mathrm{C}_{6} \mathrm{H}_{5} \mathrm{CH}_{2}$ (benzyl) $+\mathrm{H}_{2} \mathrm{CCCH} \leftrightarrow \mathrm{C}_{10} \mathrm{H}_{9}+\mathrm{H}$ was altered from the previous value of $1.0 \mathrm{E}+10 \mathrm{~cm}^{3} / \mathrm{mol} / \mathrm{sec}[8]$ to a value of $2.0 \mathrm{E}+12 \mathrm{~cm}^{3} / \mathrm{mol} / \mathrm{sec}$ so as to obtain agreement with the measured naphthalene profile. This rate constant lies approximately a factor of three higher than Colket's rate constant expression [22]. A crude QRRK calculation for benzyl+propargyl combination through the $\mathrm{C}_{6} \mathrm{H}_{5} \mathrm{CH}_{2} \mathrm{CHCCH}_{2}$ adduct was performed assuming that the rate determining step is cyclization to a multi-fused ring diradical. This step would require a higher energy barrier than the analogous cyclization step in allyl+propargyl because aromaticity in the benzene ring would have to be destroyed in order to form the diradical species. We also assumed an irreversible step to products would follow once the diradical was formed in the QRRK calculations. We have used the same inputs as stated above for allyl+propargyl, and matched the rate constant used in the modeling effort by allowing the energy barrier in the cyclization step to be a free parameter. The QRRK calculations indicate that a barrier height of 
approximately $46-48 \mathrm{kcal} / \mathrm{mol}$ will allow a match of the rate constant as derived from the numerical modeling. A barrier height greater than the stated maximum will lower the calculated rate constant and the model will underpredict the naphthalene measured in the experiment. We will present further discussion of these QRRK calculations and their implication to aromatic and polycyclic aromatic hydrocarbon formation in a future paper.

\section{CONCLUSIONS}

Detailed chemical kinetic modeling has been performed to investigate the complex chemistry occuring within an opposed-flow, methane diffusion flame. The numerical modeling results show reasonable agreement with experimental measurements for many of the larger hydrocarbon aliphatic compunds, aromatics, and PAH's. The important reaction pathways leading to the production of aromatics and $\mathrm{PAH}^{\prime}$ s were identified and all involved resonantly stabilized radicals.

The modeling results indicate benzene to be produced from fulvene, propargyl self reaction, and the reaction of phenyl with $\mathrm{H}_{2}$. Fulvene is formed entirely by the global reaction, Allyl+Propargyl $\leftrightarrow \mathrm{Fulvene}+\mathrm{H}+\mathrm{H}$. The naphthalene concentration profile could not be modelled using only the $\mathrm{c}-\mathrm{C}_{5} \mathrm{H}_{5}+\mathrm{c}-\mathrm{C}_{5} \mathrm{H}_{5}$ $\leftrightarrow$ Naphthalene $+\mathrm{H}+\mathrm{H}$ global reaction step. Like benzene, there are other alternative pathways that lead to naphthalene formation. Instead, the benzyl plus propargyl reaction was used to account for the majority of the naphthalene formed in the opposed flow, methane diffusion flame.

\section{ACKNOWLEDGEMENTS}

The authors wish to thank Dr. Carl Melius for valuable technical discussions. The computational work was supported by the U.S. Department of Energy, Office of Industrial Technology, and performed at Lawrence Livermore National Laboratory under the auspices of the U.S. Department of Energy under Contract Number W7405-ENG-48. The experimental work was supported, in part, by the US 
Environmental Protection Agency, the UCLA Center for Clean Technologies, and the Petroleum Environmental Research Forum Project 92-19. 


\section{REFERENCES}

1. Miller, J.H., Honnery, D.R., and Kent, J.H., Twenty-Fourth Symposium (International) on Combustion, The Combustion Institute, Pittsburgh, PA, 1992, pp 1031-1039.

2. Sivathanu, Y.R., and Gore, J.P., Combust. Flame, 110:256-263 (1997).

3. Colket, M.B., Hall, R.J., and Smooke, M.D., Mechanistic Models of Soot Formation, UTRC Report No. UTRC93-28, 1993.

4. Norton, T.S., Smyth, K.C., Miller, J.H., and Smooke, M.D., Combust. Sci. and Tech., 90:1 (1993).

5. Kee, R.J., Miller, J.A., Evans, G.H., and Dixon-Lewis, G., Twenty-Second Symposium (International) on Combustion, The Combustion Institute, Pittsburgh, PA, 1988, pp 1479-1494.

6. McEnally, C.S., and Pfefferle, L.D., Comb. Sci. and Tech.,116:183-209 (1996).

7. Vincitore, A. M., and Senkan, A. M., Combust Sci. and Tech, in press (1998).

8. Marinov, N.M., Pitz, W.J., Westbrook, C.K., Castaldi M.J., and Senkan, S.M. Combust. Sci. and Tech. ,116-117:211-287 (1996).

9. Marinov, N. M., Castaldi, M. J., Melius, C. F., and Tsang, W. Combust. Sci. and Tech. in press, 1997.

10. Marinov, N. M., Pitz, W. J., Westbrook, C. K., Vincitore, A. M., Castaldi, M. J., Senkan, S. M. Combust. Flame, in press, 1998.

11. Kee, R.J., Rupley, F.M., and Miller, J.A., The Chemkin Thermodynamic Database, \#SAND86-8246, 1986.

12. Stein, S.E., and Fahr, A., J. Phys. Chem., 89:3714-3725 (1985). 
13. Benson, S.W., Thermochemical Kinetics 2nd Ed., John Wiley and Sons, 1976.

14. Ritter, E.R., and Bozzelli, J.W., Int. J. Chem. Kinet., 23, 1991, pp.767-778.

15. Kee, R.J., Dixon-Lewis, G., Warnatz, J., Coltrin, M.E., and Miller, J.A., The Chemkin Transport Database, Sandia Report \#SAND86-8246 (1986).

16. Wang, H., and Frenklach, M., Combust. Flame, 96:163-170 (1994).

17. Bowman, C.T., Hanson, R.K., Davidson, D.F., Gardiner Jr., W.C., Lissianski, V., Smith, G.P., Golden, D.M., Frenklach, M., and Goldenberg, M., http://www.me.berkeley.edu/gri_mech/1997.

18. Lutz, A. E., Kee, R. J., Grcar, J. F. and Rupley, F. M., "OPPDIF: A Fortran Program for Computing Opposed-Flow Diffusion Flames," Sandia National Laboratories Report \#SAND96-8243 • UC-1409 (1997).

19 Frenklach, M., Clary, D. W., Gardiner, W. C., Jr., and Stein, S. E., Twentieth Symposium (International) on Combustion, The Combustion Institute, Pittsburgh, PA, 1985, p 887.

20. Melius, C.F., Colvin, M.E., Marinov, N.M., Pitz, W.J., and Senkan, S.M., Twenty-Sixth Symposium (International) on Combustion, The Combustion Institute, Pittsburgh, PA, 1996, pp 685-692.

21. Dean, A. M. , J. Phys. Chem., 89:4600 (1985).

22. Colket, M.B., and Seery, D.J., Twenty-Fifth Symposium (International) on Combustion, The Combustion Institute, Pittsburgh, 1994, pp. 883-891. 


\section{Figure Captions:}

Figure 1. Schematic of opposed flow diffusion flame burner.

Figure 2. Axial profiles of computed (curves) and measured (symbols) reactant concentrations. Specified radiation corrected temperature profile used in the calculation which is based on the thermocouple measurements.

Figure 3. Axial profiles of computed (curves) and measured (symbols) concentrations of water, molecular hydrogen, carbon dioxide, and carbon monoxide.

Figure 4. Axial profiles of computed (curves) and measured (symbols) concentrations of ethane, ethylene, acetylene, and total $\mathrm{C}_{3} \mathrm{H}_{4}$.

Figure 5. Axial profiles of computed (curves) and measured (symbols) concentrations of the total $\mathrm{C}_{4} \mathrm{H}_{6}, \mathrm{C}_{4} \mathrm{H}_{4}$, and $\mathrm{C}_{4} \mathrm{H}_{2}$ (diacetylene) concentrations.

Figure 6. Axial profiles of computed (curves) and measured (symbols) concentrations of benzene and substituted benzenes.

Figure 7. Axial profiles of production (positive) and consumption (negative) rates of benzene by individual reactions. The "total rate" is the sum of all production and consumption reactions.

Figure 8. Axial profiles of computed (curves) and measured (symbols) concentrations of two- and three-ring PAH's.

Figure 9. Axial profiles of computed (curves) and measured (symbols) concentrations of the four-ring PAH's.

Figure 10. Reaction paths to benzene. 


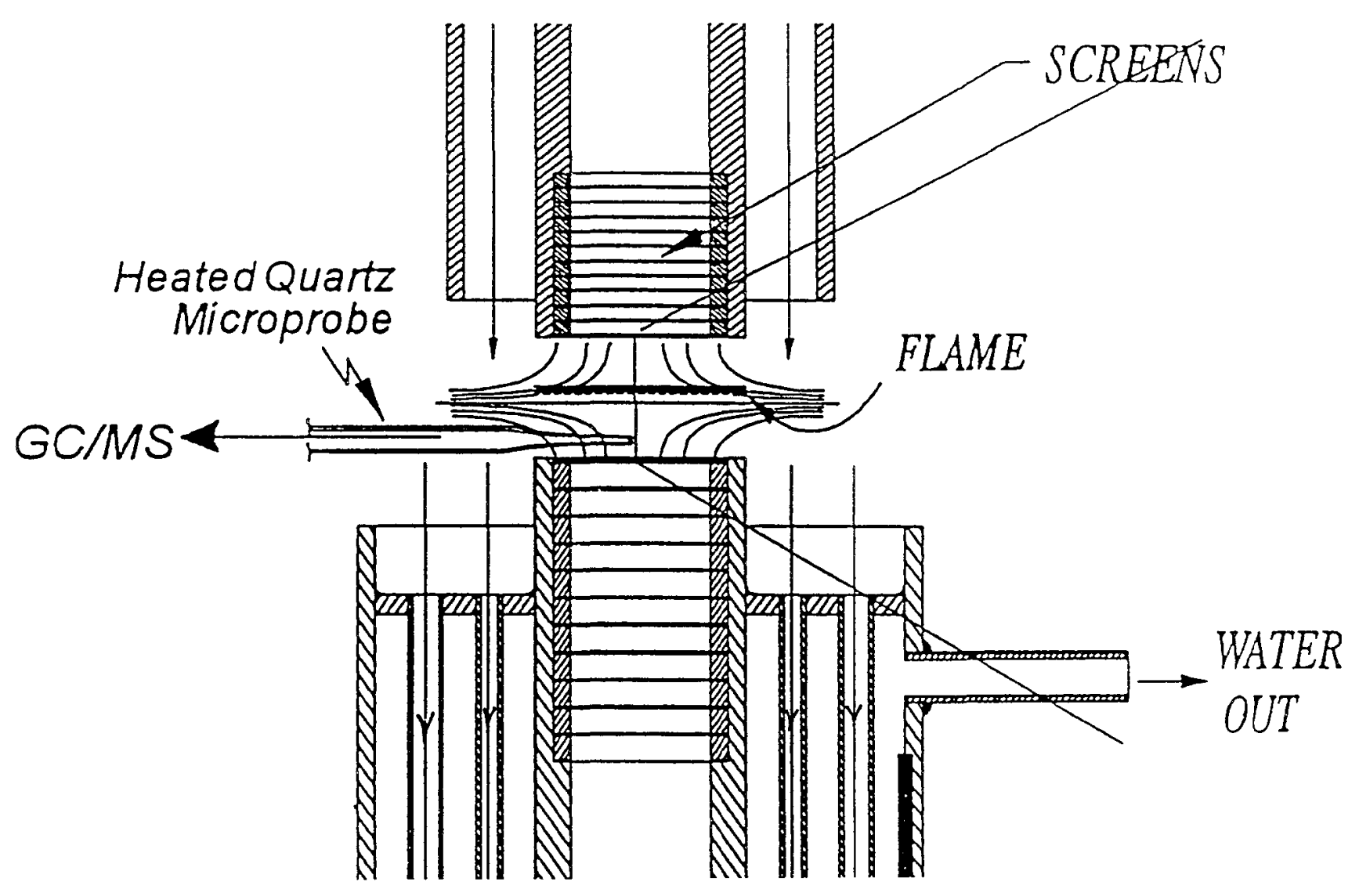

Fiy 1 


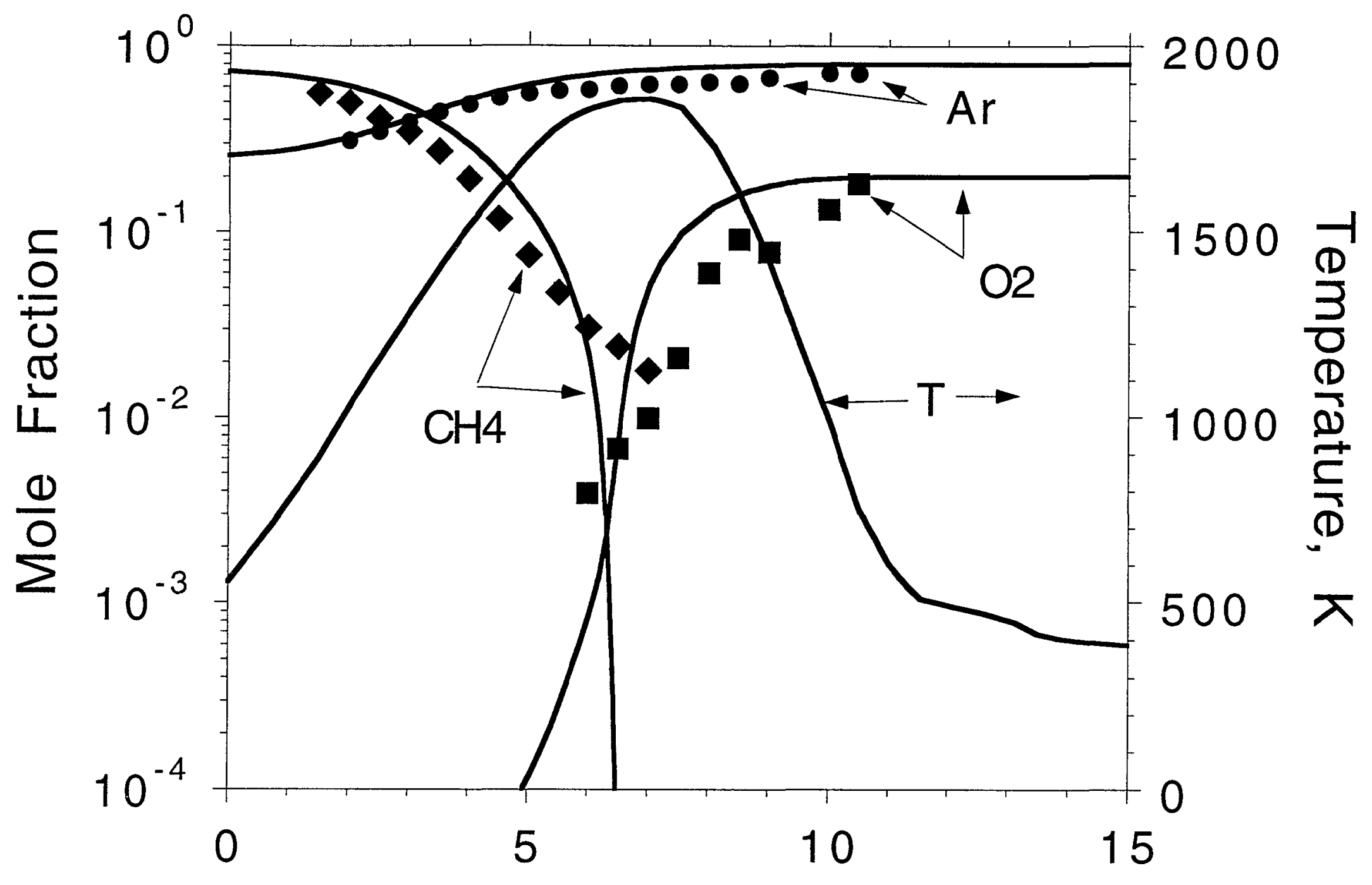

Distance from Fuel Burner Port, mm 


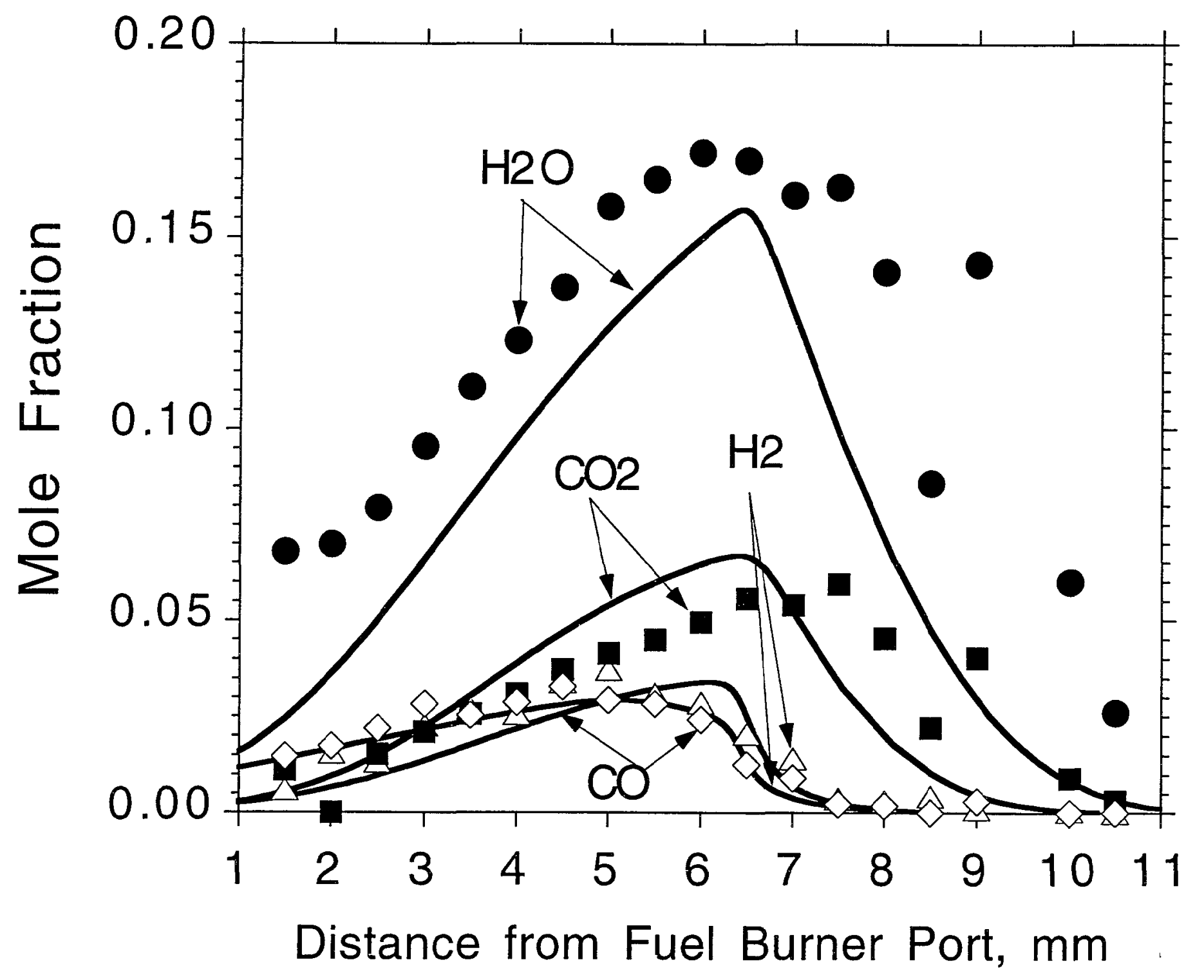

Fig. 3 


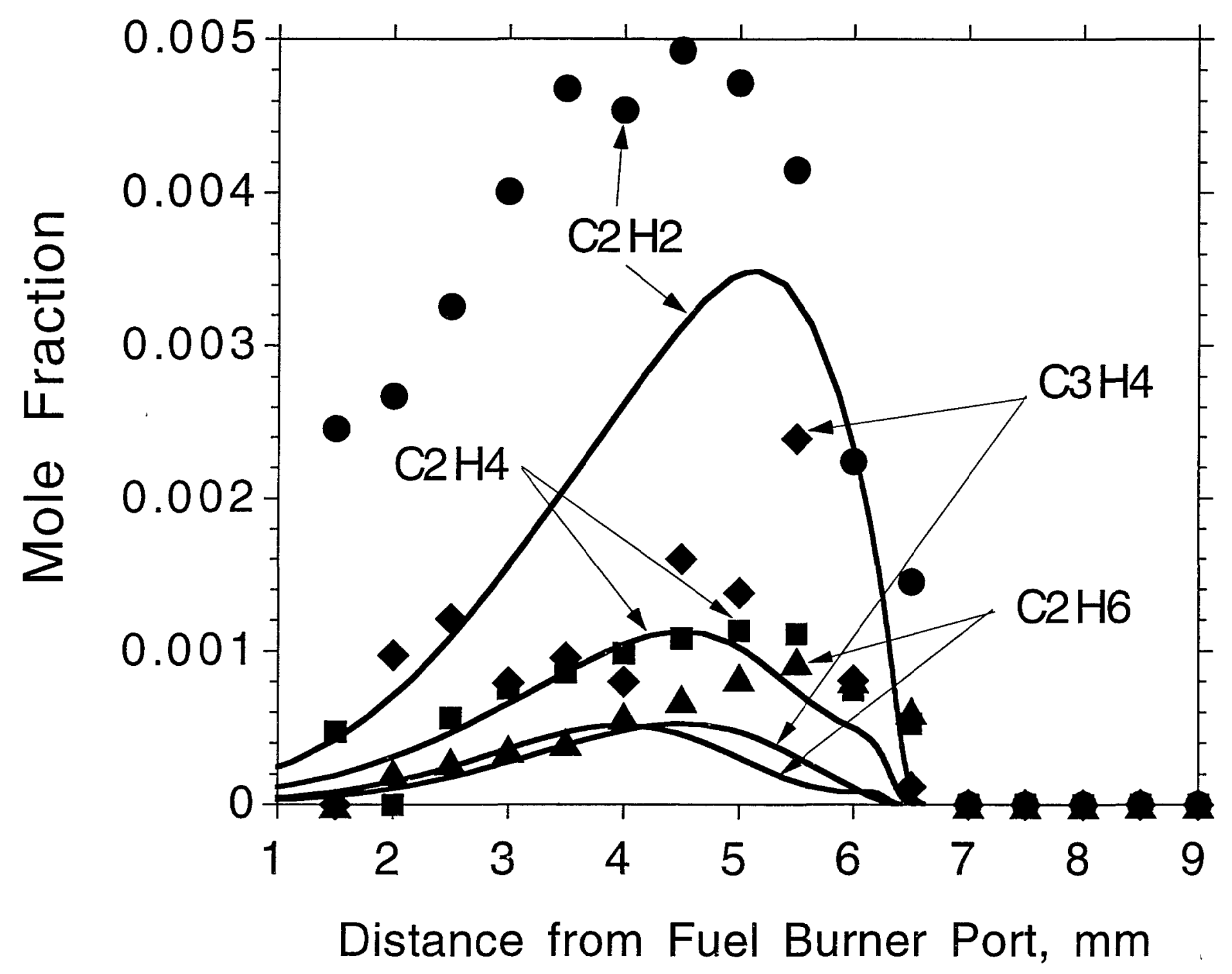

Fig. 4 


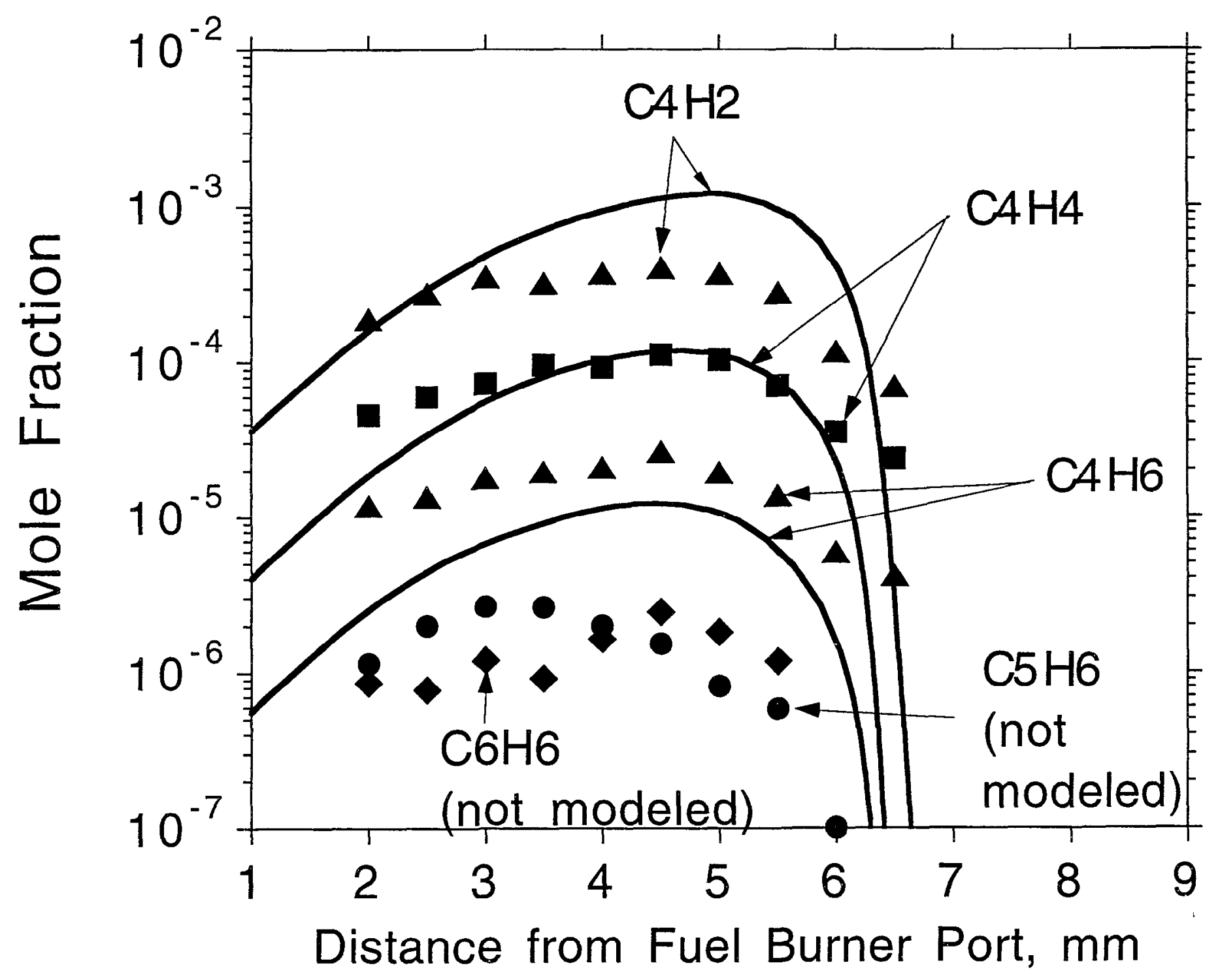

Fig. 5 


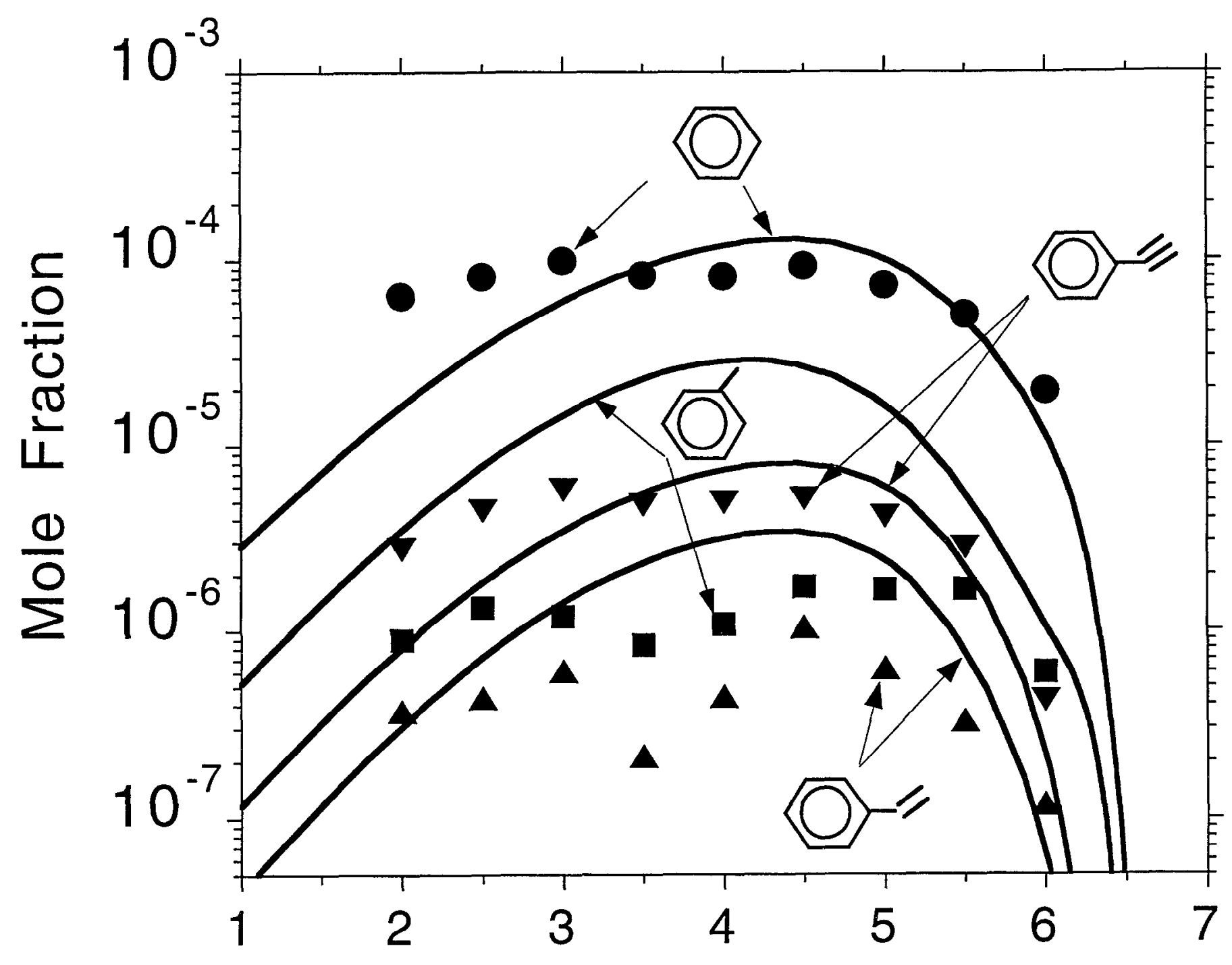

Distance from Fuel Burner Port, mm

Fig. 6 


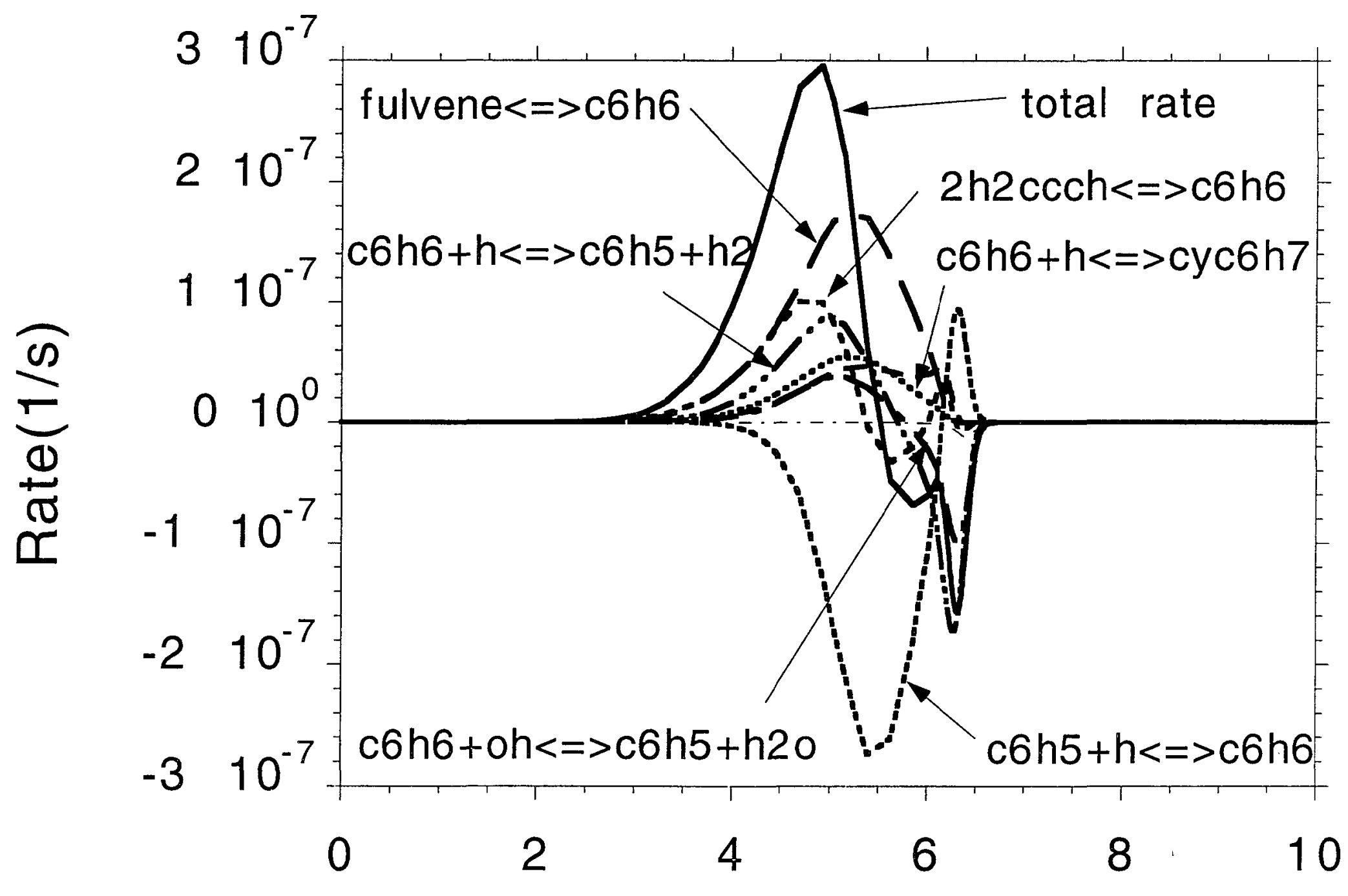

Distance from Fuel Burner Port, mm 


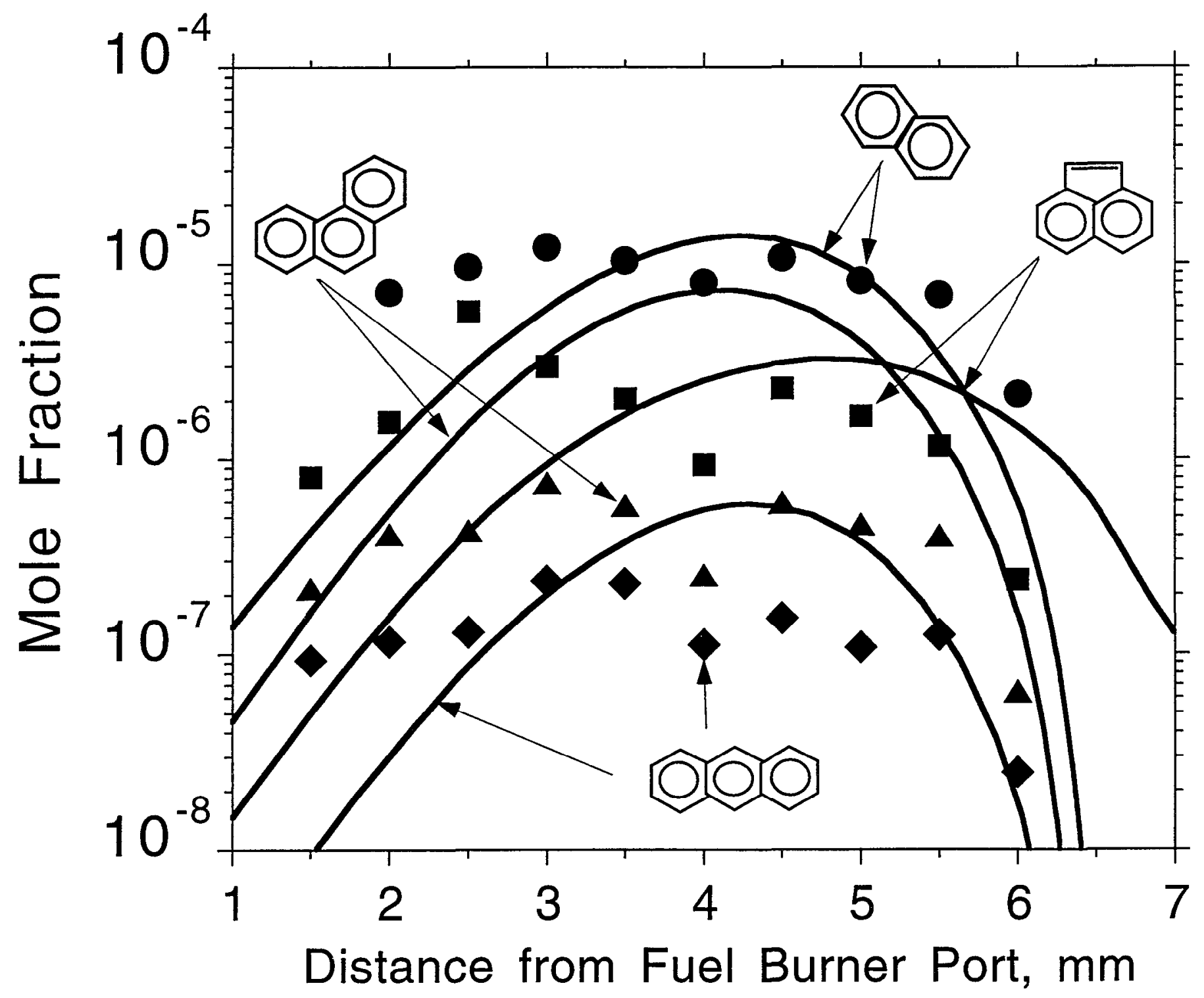

Fig. 8 


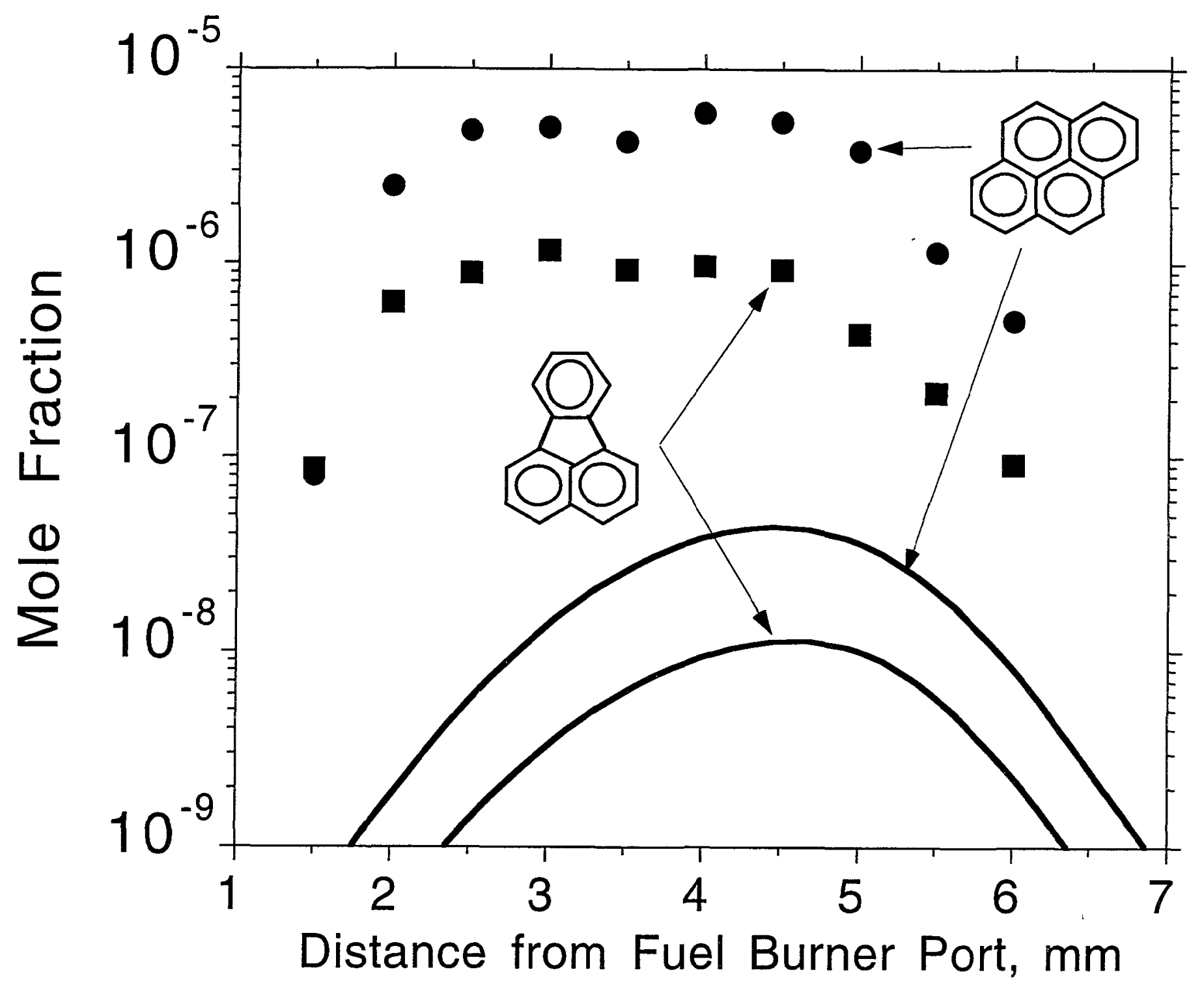

Fig. 9 


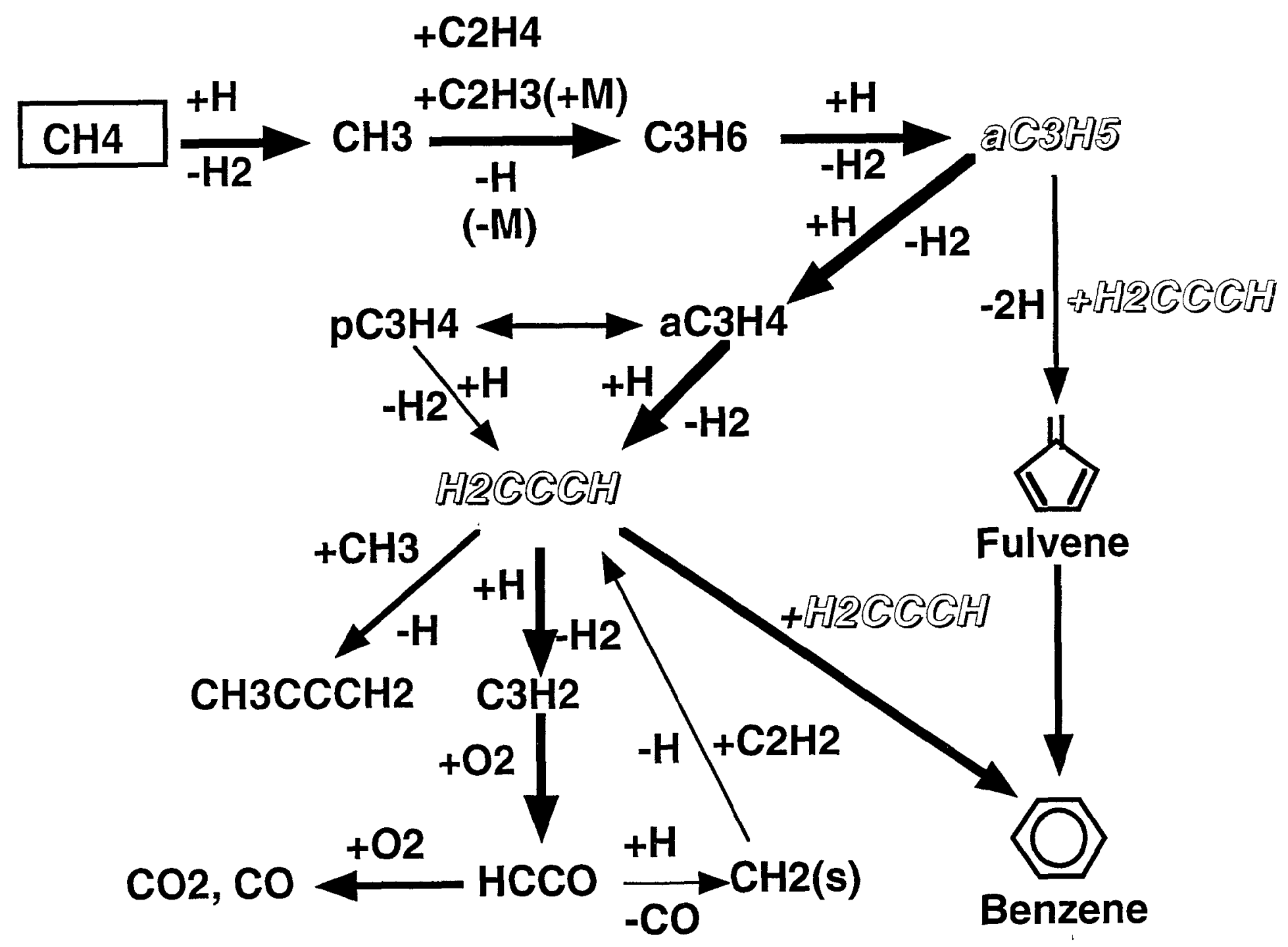

Fig. 10 


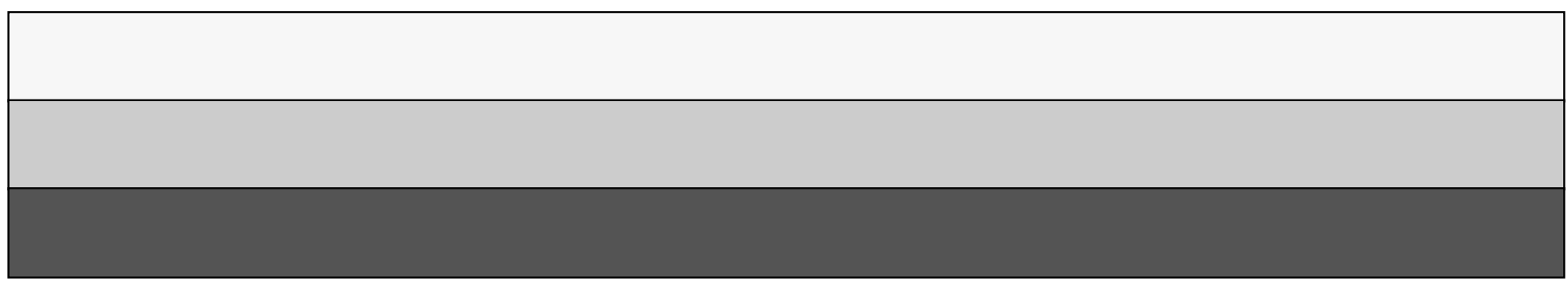

